\title{
Strain DSM 6035 is the type strain of Lactobacillus panis (Wiese et al. 1996). Opinion 72
}

\author{
Judicial Commission of the International Committee on Systematics of \\ Prokaryotes
}

Correspondence

Hans G. Trüper

trueper@uni-bonn.de
The Judicial Commission of the International Committee on Systematics of Prokaryotes decided that strain DSM 6035 is the type strain of Lactobacillus panis with the consequence that the name Lactobacillus panis has been validly published.
The Judicial Commission denied the Request for an Opinion by Dellaglio \& Klein (1997), who had questioned the valid publication of the name Lactobacillus panis by Wiese et al. (1996), because the type strain DSM 6035 at the time of its publication was not available from the publicly accessible section of any culture collection. The Judicial Commission decided that the name Lactobacillus panis, with the type strain DSM 6035, has been validly published because:

(1) In 1996, the deposition as a type strain of a strain whose access, and publication of information relating to it, was limited by a contract between the depositor and the culture collection was not in contradiction with the Rules of the Bacteriological Code (1990 Revision) (Lapage et al., 1992).

(2) Evidence was presented to the Judicial Commission that the strain had been obtained by a third party, and the strain has now been added to the publicly accessible section of the DSMZ culture collection.

\section{References}

Dellaglio, F. \& Klein, G (1997). Rejection of Lactobacillus panis (Wiese et al. 1996). Request for an Opinion. Int J Syst Bacteriol 47, 910.

Lapage, S. P., Sneath, P. H. A., Lessel, E. F., Skerman, V. B. D., Seeliger, H. P. R. \& Clark, W. A. (editors) (1992). International Code of Nomenclature of Bacteria (1990 Revision). Bacteriological Code. Washington, DC: American Society for Microbiology.

Wiese, B. G., Strohmar, W., Rainey, F. A. \& Diekmann, H. (1996). Lactobacillus panis sp. nov., from sourdough with a long fermentation period. Int J Syst Bacteriol 46, 449-453. 